\title{
"They did not need to burn the house. They could have led the Jews out and killed them off"
}

\author{
Postscript to Jerzy Mazurek and Alina Skibińska's \\ text “'Barwy Białe' on their Way to Aid Fighting Warsaw. \\ The Crimes of the Home Army against the Jews"
}

The partisans knocked - you had to take a shovel and go to the forest to bury the bodies of the "dead Jews." This is how the Jews who were hiding in the woods around Siekierno as late as August 1944 are remembered today in the villages of Kaczka, Mostki and Stawek Stary.

The memory of the place is also still present: "The Jews were killed in the Dead Forest." But despite the directions given us by the locals we did not find it. The summer was particularly rainy and the area, swampy at the best of times, became so wet, one could not drive through even in a car with a high chassis. And the directions were not exactly precise. Entire tracts of old wood had been felled and new trees have grown, so trees may now be growing in the clearing, in which the massacre was carried out. But one would still say "I was in the Dead" when coming back from there with wild mushrooms or blueberries for many years after the war.

The massacre was carried out on 17 August 1944 by the "Barwy Białe" detachment, which was a part of the $2^{\text {nd }}$ Infantry Division of the Home Army. They led the Jews to the clearing and shot them. Jerzy Mazurek and Alina Skibińska drew up an account of the crime based on the post-war trial and other sources. Witnesses, dragged out at night by partisans to dig a grave, were questioned. We tried to find them.

All of them did live in the area at the time, but now all of them are dead. In Kaczka, a small village on the edge of the forest, which is not even marked on a map, there are several well-kept small cottages. Kaczka was closest to the site of the massacre, and young men from there were woken to go and dig a mass grave. Regina Babiarz, who was nineteen at the time and lived nearby, in Mostki, is the only person who remembers the war years. We asked her about the witnesses to the massacre, giving the last names we know from the trial records. 
One hanged himself after the war; the others had died - five years ago, two years ago, three months ago.

She told us: "Jews were killed, I do not what they had done. In Skarżysko there were many Jews, there was a ghetto, they ran away and settled here. The Jews there were mixed, not only from Skarżysko. First they were robbed because they had gold, and then they were killed. They had gold because that is how they paid for food, they gave wedding rings and people gave them bread. They would come to my mother-in-law. She baked bread and gave it to the partisans and the Jews. The Jews paid, the partisans did not because they had nothing to pay with. When the Jews were killed, people from the village buried them."

"Did people know then who murdered them?" - we asked.

"Whether it was the partisans or Germans, I do not know. All I know is that about twenty Jews were killed."

"Did everyone know that?"

"Of course they did."

"And what did they say?"

"They did not say anything about the Jews because everyone was afraid for their life."

"Did they grieve for those murdered?"

"Not for the Jews, for the partisans - yes, they did."

We read her excerpts from the testimony of her father. During the war, Bolesław Bukowski was the administrator of the village of Mostki - a rather large village, which as an administrative unit included Kaczka.

"About fifty people were murdered. As I heard, they were shot by Polish partisans, and they were probably buried there. After the event, I heard that their clothes were taken off and burned on the spot because valuables, such as wedding rings, were expected to be found."

Regina Babiarz: "The Poles killed them. Right. The Germans did not know that Jews were killed there. I heard that Jews had gold sewn into their clothes."

In the testimony that we read to her, there appears the name of Jan Tuśno from Kaczka, who was designated by the partisans to dig the grave.

Regina Babiarz: Tuśno came to my father once and brought a Jew who came out of the forest to get food, and Tuśno caught him. I saw it. The Jews was middle-aged, he was bound with a noose from straw. My father told him, "I do not wish to have anything to do with Jews or with you, and I do not want to kill him. You have Germans there," because Germans were stationed in the vicinity, "go to them." The Germans had been telling people that they would get a reward. They saw that it was a Jew, killed him, and made Tuśno dig a ditch. Tuśno was an old man, he was lured by the prospect of the reward, and the reward was having to dig the grave. I am surprised he bothered to drag a man on a rope for several kilometers, a long way. When my friends and I went there to see what happened, the Jew was already buried. 
Regina Babiarz told us that her father helped a Jewish woman with a child. "At the Hermans' place, in Szelejtowo, on the second street there was a Jewish woman kept in hiding whom my father sent there." In Mostki-Szelejtowo we found Maksymilian Herman's daughter. She firmly denies it; her father did not keep any Jewish woman in hiding. She mentions another killing in the area.

"There were Jews behind the mine, they were quarrying stone for the Germans because those were quarries. Some Jews were hiding and the very Poles who knew them killed them, I heard."

For her it is obvious that Jews posed a danger during the war.

"I once saw two shaggy ones, and then one of the neighbors met them when he was picking mushrooms. He was scared out of his wits. He said, 'I ran away because they would kill me in the forest."'

We did not learn much more than that.

The husband of Mieczysława Babiarz from Suchedniów (she is Regina's sister in-law) was also forced to dig the grave. We read her his testimony: "Partisans told me to take a shovel and go with the man mentioned above and one partisan to the forest, which I did, when we reached the site, we saw a large heap of naked corpses, covered with branches [...]. We dug a grave over one meter deep, into which we pulled down the corpses. There were about fifty, and among them were women. [...] In my view and according to what people said, they were supposed to be Jews who ran away from the ghetto in Skarżysko-Kamienna." Mieczysława Babiarz recalls that after the war her husband was summoned by the Security Office.

"The partisans came to him to fetch him for the burial, and that was the end of it," she said.

Władysław Sukniewicz (born 1931), who lives on the edge of the forest, behind Kaczka reluctantly spoke to us across the fence. He told us his father was one of "Grey's" partisans.

"Were there any Jews hiding in the area?" we asked.

"It is said they were killed."

"By the partisans?"

"It was ages ago. It had to be the Germans. In this direction, a long way towards Siekierno, there were meadows. Jews had sheds. They were killed. And our partisans from 'Grey' had to dig a grave. All of the Jews died, you could hear the shots - rat-tat-tat rat-tat-tat. And then when they were finishing them off bang, bang, bang."

$$
* * *
$$

We went to search for another grave. In June 1944 the commander of the "Barwy Białe" detachment Lieutenant Kazimierz Olchowik "Zawisza" learned that the doctor in his detachment, a Second Lieutenant of the Polish Army who went by the pseudonym "Bear," was Jewish and ordered him to be shot. Bolesław Kłobuc from the gamekeeper's lodge near the village of Lisów testified at the 
post-war trial. He had found a freshly dug grave and learned in the village that "Zawisza's" group killed its doctor - a Jew. "Everyone talked about it in the village."

None of the inhabitants of the village from that time is still alive. We spoke to Bolesław's son, Adam Kłobuc.

"Father did not tell me who was killed, but he said that a man was done away with, showed me the grave, now it cannot be found because later the ground sank where the grave was and it is overgrown with trees."

He told us about another murder in the vicinity.

"It happened in Opatów, after the liquidation of the ghetto. A young Jewish woman was living in hiding near the town square and someone betrayed her. A man who was in the Home Army led her to the cemetery. My friend, Tadek Lewicki - he told me about this - followed them. He was young; he wanted to see sex in real life. But by the military cemetery, the AK partisan took out a revolver and shot the young woman in the head. I will not say who it was because it is second-hand knowledge, but when the murderer was being decorated, it was repugnant."

We went to Goździelin where members of the special unit of the Second Department of the Home Army in Ćmielów District, who later joined the "Barwy Białe" detachment, murdered seven Jews: three men, two women and two children aged six and twelve. The partisans burnt the house of Maria Czuba, who was hiding them. This is what the trial records presented in Mazurek and Skibińska's text show.

Though the village is rather large, when we walked from door to door, we found only three people who lived there during the war, three women.

Teodozja Cielebąg: "Nobody knew that Jews were hiding on the hill. It happened at night, and when Germans came in the morning, only ashes were left. Later everyone knew that Czubina's (people called her Królica) house was burnt for hiding Jews." Czuba's maiden name was Król, hence the nickname.

Amelia Wodecka (born 1924): "Why they were killed, nobody knows, someone complained about Czuba. Partisans came and instead of bringing them out and killing them outside, they killed them in the house. The woman could take only her bed and comforter, what she did not take out was burnt when they set fire to the house. The poor woman cried that she had lost her home. In the morning we hurried to see the place, and found small piles of Jews. There were six piles of the Jews who were burnt." Before we go, our interlocutor once again said that there was no need to burn the house, only "bring them out and kill them." She has good memories of the Germans. Of her own accord, she repeatedly said, "Germans were such decent people."

Our last conversation was with Amelia Wodecka's neighbor. Once again, we were talking over the fence. 
"I was ten-years-old. We ran there to look. The elderly woman took everything out of the house before it was burnt. I remember the pots."

Translated by Aleksandra Michalska

\begin{abstract}
The author visited the villages and towns where the murders of Jews hiding in the Kielce region after the liquidation of the ghettos took place (the deeds were described in Jerzy Mazurek and Alina Skibińska's text published in this volume). Only a few of the inhabitants, who were there during the war, remain, but the memory of the murdered Jews is still present. Both the memory of those killed by the passing Home Army detachment (and who were buried by the locals who were ordered to do so) and the memory of those denounced by the locals, killed on the spot or escorted to a German police station. Memory does not always entail compassion. The article proves that field research, even when conducted so many years after the Holocaust, can bring additional knowledge to historical research.
\end{abstract}

\title{
Key words
}

Holocaust remembrance, Polish-Jewish relations, field research 